\title{
Aprepitantın İnsan Glioblastoma U87MG Hücreleri üzerinde Antiproliferatif ve Apoptotik Etkileri
}

\author{
Miriş DİKMEN
}

\section{ÖZ}

Glioblastoma multiforme, gliomalar arasında en malign özellikte olup, görülme sıklığı oldukça yüksektir. Hızlı çoğalma, beyin dokusuna invazyon ve migrasyon gibi agresif özelliklere sahiptir. Bu nedenle son yıllarda glioblastoma kemoterapisinde, yeni tedavi hedeflerinin gelişmesini üzerine çalışmalar yoğunlaşmıştır. Substans P, nörokinin-1 (SP/NK-1) reseptör sistemi, kanser gelişimi ve kanser metastazında önemli bir rol oynamaktadır. $\mathrm{Bu}$ nedenle NK-1 reseptörleri, glioblastoma tedavisinde ve NK-1 reseptör antagonistlerinin gelişiminde yeni tedavi hedefleri arasında yer almaktadır.

$\mathrm{Bu}$ çalışmada, klinikte özellikle kemoterapi sırasında antiemetik amaçla kullanılan, bir NK-1 reseptör antagonisti olan aprepitantın, insan malignant glioblastoma U87MG hücre hattında antiproliferatif ve apoptotik etkileri araştırılmıştır. Çalışmada MTT yöntemi ve gerçek zamanlı hücre analiz sistemi (RTCA DP) ile hücre proliferasyon analizleri, anneksin V-PI ve kaspaz 3 flow sitometri analizleri ile de apoptotik etkiler çalışılmıştır. MTT analizine göre aprepitantın konsantrasyon ve zamana artışına bağlı olarak U87MG hücreleri üzerinde sitotoksik etki yaptığı ve U87MG hücre proliferasyonunu azalttığı görülmüştür. Gerçek zamanlı analiz sisteminden elde edilen hücre indeks değerlerine göre de, $50 \mu \mathrm{M}$ ve üzeri aprepitant konsantrasyonlarında hücre proliferasyonunun azaldığı ve sırasıyla $\mathrm{IC}_{50}$ değerlerinin 24 . saatte $76.9 \mu \mathrm{M}, 48$. saatte $62.5 \mu \mathrm{M}$ ve 72 . saatte de $59.2 \mu \mathrm{M}$ olarak belirlenmiştir. Flow sitometri analiz sonuçlarına göre aprepitantın 24. saatteki erken ve geç apoptotik etkisi konsantrasyon artışına bağlı olarak artış göstermiştir. Özellikle $\mathrm{IC}_{25}$ ve $\mathrm{IC}_{50}$ aprepitant değerlerinde aktif kaspaz-3 değeri kontrole göre, az da olsa artmıştır. Sonuç olarak aprepitantın malignant glioblastoma U87MG hücrelerinde önemli antiproliferatif ve apoptotik etkileri belirlenmiş olup, NK-1 reseptör antagonistlerinin yeni bir terapötik hedef olabileceği düşünülmektedir.

Anahtar kelimeler: NK-1, aprepitant, U87MG, apoptoz, antiproliferatif
Miriş Dikmen

Anadolu Üniversitesi, Eczacılık Fakültesi, Farmakoloji ABD ve Klinik Eczacıllk $A B D$, Eskişehir, Türkiye

e-posta:mirisd@anadolu.edu.tr

Submitted / Gönderilme: 21.06.2016 Accepted / Kabul: 06.10.2016

Revised / Düzeltme: 10.08.2016

\section{GíRİs}

Gliomalar beyin dokusundan kaynaklanan tümörlerdir ve histopatolojik olarak malignite dereceleri farklılık göstermektedir. Dünya Sağlık Örgütü sınıflamasına göre glioblastoma multiforme (evre IV), gliomalar arasında en malign olanı ve en sık görülenidir. Hızlı çoğalma, beyin dokusuna invazyon, nekroz, anjiyogenez, mikrovasküler proliferasyon ve migrasyon gibi agresif özelliklerie sahiptir. Glioblastoma kemoterapisinde yeni tedavi hedefleri geliştirmek için son yıllarda yoğun araştırmalar yapilmaktadır $(1,2)$. Astrositlerden orjin alan malignant glial hücrelerin oluşturduğu beyin tümörlerinde, hücre NK(Nörokinin) reseptörleri, taşikininler (Substans P (SP) ve nörokinin A (NKA) gibi) tarafından uyarılır. Hücre içi uyarı mekanizmaları tetiklenir ve hücrede başta sitokinler olmak üzere çeşitli aracı moleküller salgılanarak, hücre proliferasyonu gerçekleşir. Birçok in vivo ve in vitro 
çalışmada SP’nin insan gliomalarında tetikleyici bir rolü olduğu ve dolayısıyla tümör progresyonun devamlılığının sağlanmasında etkili olduğu bildirilmiştir $(1,3)$.

SP/NK-1 reseptör sistemi kanser gelişimi ve kanser metastazında önemli bir role sahiptir. Bazı çalışmalarda, NK-1 reseptör antagonistlerinin, antikanserojenik etkilerinin olabileceği rapor edilmiştir (4). SP, hem santral hem de periferal sinir sisteminde dağılım gösterir ve nörokinin-1 (NK-1) reseptörüne bağlanarak hücresel işlevlerini başlatmaktadır (5). Özellikle tümör hücrelerinde SP ve NK-1 reseptörleri fazla eksprese olmaktadır. Normal hücrelerde eksprese edilen NK-1 reseptör sayısı, tümör hücreleri tarafindan eksprese edilenden daha düşüktür (6). SP, spesifik nörokinin-1 (NK-1) reseptörüne bağlanınca, tümör hücrelerinin proliferasyonu, anjiyogenezi, invazyonu ve metastazı gibi kanserle ilişkili hücre içi birçok biyolojik olayları tetiklenmektedir (7-9). Buna karşılık, NK-1 reseptör antogonistlerinin, spesifik reseptörlerine bağlanması sonucunda da, tümör hücre proliferasyonu ve hücre migrasyonu inhibe ettiği bilinmektedir. Bu nedenle NK-1 reseptörleri kanser hücrelerinin tedavisinde ve kullanılacak yeni NK-1 reseptör antagonistlerinin gelişiminde yeni bir hedef olarak görülmektedir (7) .

Aprepitant olarak da bilinen ve bir NK-1 antagonisti olan MK-869, klinikte antiemetik bir ilaç olarak kullanılmaktadır (10). Aprepitant, selektif ve yüksek afiniteli NK-1 reseptör antagonistidir (11). Aprepitant FDA tarafından, yüksek doz sisplatin dahil yüksek düzeyde emetojenik (kusmaya neden olan) kanser kemoterapisi uygulanan hastalarda, kemoterapiye bağlı akut ve geç kusma durumları için, bir kortikosteroid ve bir 5-HT3 antagonisti ile kombine kullanılmaktadır. Aprepitant kan-beyin engelini aşarak, beyin dokusundaki NK-1 reseptörlerine sellektif olarak bağlanır (12).

NK-1 reseptör antagonisti L-733,060 (piperidin türevi)'nin SP yi inhibe ederek, kanser hücrelerinden yüksek oranda eksprese edilen NK-1 reseptörünün metastatik etkilerini inhibe ettiği bildirilmiştir (13). Son zamanlarda SP/NK-1 reseptörünün meme kanserinin nüks etmesiyle ilişkili olabileceği de açıklanmıştır (6). L-733,060' ve L-732,138 gibi NK-1 reseptör antagonistlerinin, insan melonoma, nöroblastoma, glioma, retinoblastoma, pankreas, larinks, mide ve kolon gibi kanser hücre hatlarında antitümör aktivite gösterdiği de rapor edilmiştir (10).

Kanser tedavisinde NK-1 reseptörünün patofizyolojik önemini daha iyi anlamak için, NK-1 reseptörlerine son derece seçici agonist ve antagonistlerinin gelişimi önem taşımaktadır. Biz de bu çalışmada, klinikte kanser kemoterapisinde görülen bulantı ve kusmaların önlenmesi amaciyla kullanılan bir NK-1 reseptör antogonisti olan aprepitantın, insan glioma U87MG hücreleri üzerinde antiproliferatif ve apoptotik etkilerini araştırmayı amaçladık.

\section{YÖNTEMLER}

\section{Hücrelerinin Kültür Ortamında Çoğaltılması}

U87MG (glioblastoma; astrocytoma) hücre hatt1, HTB-14 kodu ile ATCC (AmericanType Cell Culture) Amerika Hücre Bankası'ndan temin edilmiştir. İnsan U87MG hücre hatt1, astrositoma hücre kaynaklı, epitel kökenli bir glioblastomadır, IV evre özelliğinde olup malignant karakterdedir. U87MG hücreleri, \% 10 fötal sığır serumu, \% 1 penisilin-streptomisin, $\% 1 \mathrm{~L}$-glutamin, Eagle's Minimum Essential Medium içeren özel besiyerinde $\% 5 \mathrm{CO}_{2}^{\prime}$ li etüvde $37^{\circ} \mathrm{C}$ 'de kültür ortamında çoğaltılmıştır. Çoğaltılan hücrelerin bir kısmı, stoklanarak proje çalışmasının sonraki deneylerinde kullanılmıştır.

\section{MTT Yöntemi ile Sitotoksisitenin Belirlenmesi}

$\mathrm{Bu}$ yöntem in vitro koşullarda hücre metabolizmasını, canlılığ 1 ve sitotoksisiteyi ölçmek için uygulanan kantitatif kolorimetrik bir yöntemdir. $\mathrm{Bu}$ yöntem, canlı hücrelerdeki mitokondriyal dehidrogenaz enzim aktivitesine dayanmaktadır. Hücrelerin MTT (3-(4,5-dimetiltiyazol-2il)-2,5-difenil tetrazolyum bromür) indirgeme özelliği, hücre canlılığının ölçütü olarak alınır ve MTT analizi sonucunda elde edilen boya yoğunluğu, canlı hücre sayısıyla korelasyon gösterir (14-16).

Hücreler cedex cihazında sayılmı̧ ve 96 kuyucuklu plakalara her bir kuyucukta 5.000 hücre olacak şekilde besiyeri ortamına ekilmiş, yapışmaları için inkübasyona bırakılmıştır. DMSO'da çözülerek hazırlanmış olan aprepitant stok solüsyonundan, hücre kültür besiyeri içinde gerekli seyreltmeler yapılarak aprepitantın çalışma konsansantrasyonları (3.12, 6.25, $12.5,25,50,100,200$ ve $300 \mu \mathrm{M})$ hazırlanmış ve hücreler üzerine uygulanmıştır. Kontrol grubundaki hücrelere de \% 0.1 oranında DMSO içeren besiyeri uygulanmıştır. Daha sonra plakalar 24 ve 48 saatlik inkübasyonlara bırakılmıştır. Her bir inkübasyon süresi sonunda, hazırlanan MTT çalışma solüsyonundan $(0.5 \mathrm{mg} / \mathrm{mL})$, plakaların her bir kuyucuğuna $10 \mu \mathrm{l}$ ilave edilmiş ve plakalar $3-4$ saat $37^{\circ} \mathrm{C}$ lik 
etüvde inkübasyona bırakılmıştır. İnkübasyon sonunda her kuyucuğa çözücü olarak $100 \mu \mathrm{L}$ DMSO konulmuştur ve 540 $\mathrm{nm}$ dalga boyunda ELİZA cihazında absorbans değerleri, her bir grupta 8 kuyucuk olacak şekilde okunmuştur. Elde edilen absorbans değerleri, hücrelerin metabolik aktivitelerini verir ve bu değer de yaşayan hücre sayısı ile ilişkilendirilmiştir. Sonuçlar aşağıdaki canlılık formülüne göre hesaplanıp \% olarak belirlenmiştir.

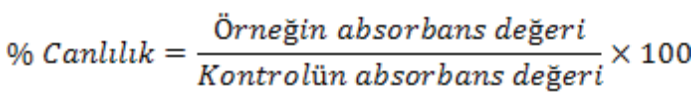

İstatistiksel Analiz: Örneklere ait MTT absorbans değerleri $(\mathrm{n}=8), \%$ canlılık değerleri olarak hesaplanmıştır. Örneklerin $\%$ hücre canlılık değerleri kullanılarak SPSS 15 (Statistic Program for Social and Science) yazilım programinda, kontrolün hücre canlılığı \% 100 kabul edilerek grupların $\%$ canlılık değerleri 'ortalama \pm S.D (Standart Sapma)' hesaplanmış ve sonuçlar tek yönlü ANOVA ve post hoc olarak Tukey s'b testi ile analiz edilmiştir. Anlamlılık değerleri; $p>0.05$ fark yok, $p<0.05^{\star}$ fark var, $p<0.01^{\star *}$ önemli derecede fark var, $p<0.001^{* * *}$ çok önemli derecede fark var olarak değerlendirilmiştir.

\section{Gerçek Zamanlı Hücre Analiz Sisteminde (RTCA DP) Antiproliferatif Etkilerinin Araştırılması}

Gerçek Zamanlı Hücre Analiz Sistemi (RTCA DP, Roche), elektriksel empedans ölçerek hücre canlılığını tespit eder ve günlerce, istenilen aralıklarla bu ölçümü devam ettirerek gerçek zamanlı veriler oluşturur. Ölçümün gerçekleşmesi için, hücrelerin, altın elektrot kaplı hücre kültürü kabının (E-plaka) tabanına tutunabilmesi gerekmektedir. E-plakadan sistem tarafından alınan değerler, literatürde kabul edilen birimsiz 'hücre indeks (cell index (CI))' değeri olarak hesaplanır. Bu değer, hücreler E-plakanın tabanını kaplayıp çoğaldıkça verilen elektriksel yanitla paralel olarak $\operatorname{artar}(17,18)$.

Gerçek zamanlı hücre analiz sisteminde (RTCA DP) uygulanacak olan aprepitant konsantrasyonları, ön tarama testimiz olan MTT yöntemi ile belirlenmiştir. Gerçek zamanlı hücre analiz sisteminde aprepitantın 12.5, 25, 50, 75, 100, 200 $\mu$ Mkonsanrasyonlarının U87MGhücrelerindeantiproliferatif etkileri çalışılmıştır. Proliferasyon çalışmasında altın elektrot kaplı E-plakalar kullanılmıştır. Sayımı yapılan U87MG hücreleri her bir E-plaka kuyucuğuna $100 \mu \mathrm{L}$ besiyeri içinde 10.000 hücre ekilmiş ve plakalar daha sonra RTCA DP cihazına yerleştirilmiş ve saatte 1 ölçüm alacak şekilde cihaz programlandıktan sonra deney başlatılmıştır. U87MG hücreleri belirli bir hücre indeks değerine ulaşınca hücrebesiyeri karışımından $100 \mu \mathrm{L}$ çekilip atılmıştır ve taze hazırlanan aprepitant konsantrasyonları $(12.5,25,50,75$, 100, $200 \mu \mathrm{M})$ E-plaka kuyucuklarına $100 \mu \mathrm{L}$ medyum içinde uygulanmıştır. E-plakalar cihaza yerleştirilmiş ve program kaldığı yerden devam ettirilmiştir. 72 saat sonra RTCA DP ile elde edilen hücre indeks değerlerine göre, aprepitant için $\mathrm{IC}_{50}$ değerleri RTCA DP Software 1.2.1 programı kullanılarak hesaplanmıştır.

\section{Akım Sitometride Annexin V-PI Yöntemi ile Apoptotik Etkinin Belirlenmesi}

$\mathrm{Bu}$ yöntem, sağlıklı hücre zarlarının iç kısmında bulunan fosfatidilserinin, apoptotik hücrelerde hücre zarında meydana gelen değişiklikler ile birlikte hücrenin dış kısmına çıkması temeline dayanır. Bu yer değiştirme hücre membran bütünlüğünün bozulmadığı apoptotik hücre ölümünün erken döneml resüspanse edilerek üzerine $10 \mu \mathrm{L}$ antikor (PE Rabbit Antikaspaz- erinde meydana gelir. Annexin V, hücrenin dış yüzeyine yerleşen fosfatidilserine bağlanabilen bir protein olduğu için, floresan bir madde (FITC gibi) ile işaretlenerek apoptotik hücre görünür hale getirilebilir (19- 22). Propidyum iyodür (PI) ise, DNA ya da çift sarmallı RNA' ya bağlandığından, membran yapısı bozulmuş geç apoptotik ve nekrotik hücrelerin tespitinde kullanılmaktadır (23). Annexin V-FITC (green fluorescence) ve non-vital boya olan propidium iodide (red fluorescence) ile aynı zamanda boyanan hücreler, canlı hücreler ([Annexin V - /PI -]), erken apoptotik hücreler ([Annexin V+ / PI -]), geç apoptotik hücreler ([Annexin V+ / $\mathrm{PI}+])$ ve nekrotik hücrelerin ([Annexin V- /PI +]) birbirinden ayırt edilmesine izin verir (21).

Apoptotik etki, Annexin V-FITC Apoptosis Detection Kit (Katolog no: 556547, BD) ve protokolüne göre çalışılmıştır. U87MG hücreleri besiyeri ortamında, $37^{\circ} \mathrm{C}$ de $\% 5 \mathrm{CO}_{2}$ inkübatöründe kültüre edilmiştir. Hücrelerin yeterince çoğalması beklendikten sonra hücre sayımı yapılarak hücreler, 6 kuyucuklu plakalara her bir kuyucukta $1 \times 10^{5}$ hücre olacak şekilde besiyeri ortamında ekilmiştir ve yapışmaları için 24 saat inkübasyona bırakılmıştır. Gerçek Zamanlı Hücre Analiz Sistemi (RTCA DP) testinin sonuçlarına göre seçilen aprepitant konsantrasyonları $\left(\mathrm{IC}_{25}: 38.5 \mu \mathrm{M}, \mathrm{IC}_{50}: 77\right.$ $\mu \mathrm{M}$ ve $\left.\mathrm{IC}_{75}: 115.5 \mu \mathrm{M}\right)$ hazırlanmış ve hücreler üzerine uygulanmıştır. Kontrol grubundaki hücrelere de \% 0.1 oranında DMSO içeren besiyeri uygulanmıştır. Daha sonra 
plakalar 24 saatlik inkübasyonlara bırakılmıştır. İnkübasyon sonunda her bir 6’lık kuyucuktaki hücreler kaldırılarak 1200 rpm’de 5 dakika santrifüj edilmiş ve supernatant uzaklaştırılmıştır. Hücre peleti $2 \mathrm{ml}$ soğuk PBS ile $2 \mathrm{kez}$ yıkanmıştır. Son yıkamadan sonra kalan pellet $100 \mu \mathrm{L}$ PBS ile resuspanse edilerek flow tüpüne aktarılmış, üzerine 5 $\mu \mathrm{L}$ Annexin V ve $3 \mu \mathrm{L}$ PI ilave edilmiştir. Oda sıcaklığında ve karanlıkta 20 dakika inkübasyona birakılan tüplerin inkübasyon sonunda $250 \mu \mathrm{L}$ "Annexin V bağlama tamponu" eklenerek 30 dakika içinde akım sitometri cihazında (FACS Aria FACS Aria flow cytometer, BD) okuması yapılmıştır ve analizi için FACSDiva Versiyon 6.1.1. Software kullanılmıştır $(16,24)$.

\section{Akım Sitometride Kaspaz-3 Aktivasyonu ile Apoptotik Etkinin Belirlenmesi}

Kaspazlar gerekölüm reseptörleri yolu, gerekse mitokondriyal apoptozda rol alan proteazlardir (25). Kaspaz-3, apoptoz mekanizmasinın tamamlanma fazında yer alan ve apoptozun sonlandirılmasından sorumlu (sonlandirıcı) kaspazlardan biridir. Kaspaz-3 hem dişsal apoptotik yolak üzerinden, hem de içsel (mitokondriyal) apoptotik yolak üzerinden aktifleşebilir. Kaspaz-3, kromatin kondensasyonundan, DNA fragmentasyonundan ve hücre iskeletine ait proteinlerin yıkımından sorumludur Bu nedenle bir hücrede kaspaz-3 enzim aktivitesinin belirlenmesi, o hücrenin apoptoza gittiğinin en önemli kanıtlarından biridir (26).

Kit içeriğinde kullanılan solüsyonlar ile (Cytofix/Cytoperm) hücreler önce geçirgen hale getirilmiş ve daha sonra PE Rabbit Anti-Aktif kaspaz-3 ile boyanarak akım sitometri cihazında FACSDiva Versiyon 6.1.1. Software kullanılarak analizi yapılmış ve aktif kaspaz-3 yüzdeleri belirlenmiştir.

Kaspaz-3 aktivasyonun belirlenmesinde PE Active Caspase-3 Apoptosis Kiti (Katalog No: 550914, BD) kullanılmıştır. U87MG hücreleri $1 \times 10^{5}$ hücre/mL yoğunluğunda olacak şekilde 6 kuyucuklu plakalara ekilmiştir. Hücreler aprepitant konsantrasyonları $\left(\mathrm{IC}_{25}: 38.5 \mu \mathrm{M}, \mathrm{IC}_{50}: 77 \mu \mathrm{M}\right.$ ve $\left.\mathrm{IC}_{75}: 115.5 \mu \mathrm{M}\right)$ ile 24 saat inkübasyona bırakılmıştır. Inkübasyon süresi sonunda her bir 6'llk kuyucuktaki hücreler kaldırılarak 1200 rpm’de 5 dakika satrifüj edilmiş ve süpernatant uzaklaştırılmıştır. Hücre peleti soğuk PBS ile 2 kez yıkanmıştır. Son yıkamadan sonra tüplerin üzerindeki süpernatant dökülmüş ve pelletin üzerine fiksasyon ve hücrelerin geçirgenliğini sağlamak için, $500 \mu \mathrm{L}$ cytofix/ cytoperm çözeltisi ilave edilerek $20 \mathrm{dk}$ buzun içinde bekletilmiştir. Bu sürenin sonunda $1200 \mathrm{rpm}$ de $5 \mathrm{dk}$ santrifüj yapılmış ve pellet $2 \mathrm{kez} 500 \mu \mathrm{L}$ "perm wash” ile yıkanmıştır. Son yıkamadan sonra hücre pelleti $50 \mu \mathrm{L}$ perm wash ile resüspanse edilerek üzerine $10 \mu \mathrm{L}$ antibody (PE Rabbit Antikaspaz-3) eklenmiş ve $30 \mathrm{dk}$ oda 1 sısında inkübe edilmiştir. İnkübasyon süresi sonunda her bir tüpe $1000 \mu \mathrm{L}$ perm wash ilave edilerek santrifüj edilmiştir. Santrifüj sonunda pellet $350 \mu \mathrm{L}$ perm wash ile flow tüpüne aktarılarak akım sitometri cihazında analiz edilmiştir $(16,24)$.

\section{Akridin Turuncusu (Akridine Orange) Floresan Boya ile Apoptotik Hücrelerin Morfolojik İncelenmesi}

NK-1 reseptör antagonisti olan aprepitantın apoptotik etkisini mikroskobik düzeyde araştırmak için akridin turuncusu ile boyama yöntemi kullanılmıştır Bunun için; U87MG glioma hücreleri kültür ortamında coverslip'ler üzerine kültüre edilmiştir. 24 saat sonra U87MG hücrelerine aprepitant konsantrasyonları $(38.5,77$ ve $115.5 \mu \mathrm{M})$ ile 24 saat inkübe edilmiştir. İnkübasyon sonunda hücreler PBS ile yıkanmış ve \%70'lik etanol ile 30 dakika fikse edilmiştir. PBS ile yıkamayı takiben hücreler, akridin turuncusu (AO) $(10 \mathrm{mg} / \mathrm{mL})$ (Sigma), boyası ile $37^{\circ} \mathrm{C}$ 'de 10 dakika karanlıkta inkübe edilmiştir. Daha sonra boya uzaklaştırılarak hücreler PBS ile yıkanmış ve hücrelerin floresan mikroskobunda (Leica DM300) görüntülenerek fotoğrafları çekilmiştir (27).

\section{BULGULAR ve TARTIŞMA}

\section{MTT Yöntemi İle Sitotoksisitenin Değerlendirilmesi}

Şekil 1'de görüldüğü gibi, insan glioblastoma U87MG hücre hattı üzerinde kontrole göre, aprepitantın konsantrasyon ve zamana bağlı olarak sitotoksik etki yaptığı, hücre proliferasyonunun azaldığı görülmüştür. Kontrole göre \% hücre canlık değerleri, aprepitant konsantrasyon artış sırasına göre 24. saatte 85.02, \%77.71, \%76.18, \%73.42, \%63.79, \%52.21, $\% 42.64, \% 42.57 ; 48$. saatte de $\% 71.36 \% 69.48 \% 71.16 \% 56.91$, \%49.39, \%40.68, \%32.71, \%32.85 olarak belirlenmiştir. Munoz ve arkadaşları farklı hücrelerin kullanıldığı bir çalışmada, aprepitantın (5-80 $\mu \mathrm{M}$ konsantrasyon aralığında) MG-63 (insan osteosarkoma), HEK293 (insan ebriyonik böbrek), GAMPK (insan glioblastonma) ve MRC-5 (insan akciğer fibroblast) hücrelerinde proliferasyonu azaltıcı etkisi MTS sitotoksisite yöntemi ile belirlenmiştir (28). Munoz ve arkadaşları H-69 küçük hücreli akciğer kanseri ve COR-123 küçük hücreli olmayan akciğer kanseri hücrelerinde de, nörokinin-1 reseptör antagonistlerinden aprepitant, L-733,06 ve L-732,138'in antiproliferatif ve apoptotik etkileri olduğunu açıklamışlardır (29). 


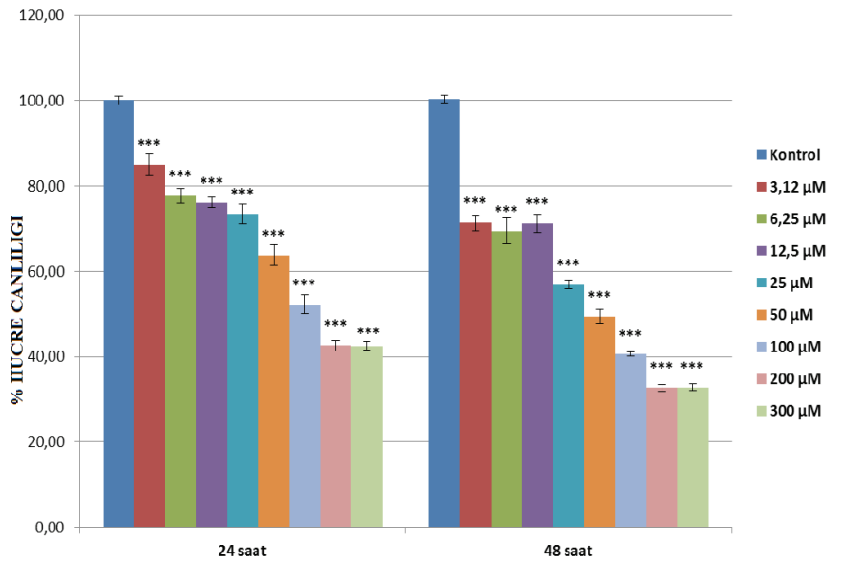

Şekil 1. Aprepitant konsantrasyonlarının, U87MG hücrelerinde MTT absorbans sonuçlarına göre 24 ve 48 . saat $\%$ hücre canlılık grafiği ve istatistiksel olarak değerlendirilmesi (Kontrol: medyum içinde \% $0.1 \mathrm{DMSO}, \mathrm{n}: 8$, ortalama \pm S.D, $\left.p<0,001^{* * *}\right)$.

\section{Gerçek Zamanlı Hücre Analiz Sisteminde (RTCA DP) Antiproliferatif Etkinin Değerlendirilmesi}

Gerçek zamanlı olarak (RTCA-DP, Roche) sisteminde, MTT yöntemine göre belirlediğimiz aprepitant konsantrasyonları $(12.5,25,50,75,100,200 \mu \mathrm{M})$, U87MG hücrelerine uygulanmış ve hücre proliferasyonları, hücre indeks değerlerine göre, bilgisayar bağlantılı sistemle eş zamanlı olarak izlenmiştir (Şekil 2). Aprepitantın U87MG hücreleri üzerindeki $\mathrm{IC}_{50}$ değerleri zamana bağlı olarak $(24,48$ ve 72 . saatlerde) hücre indeks grafiği analiz sistemi ile hesaplanmıştır (Şekil 3).

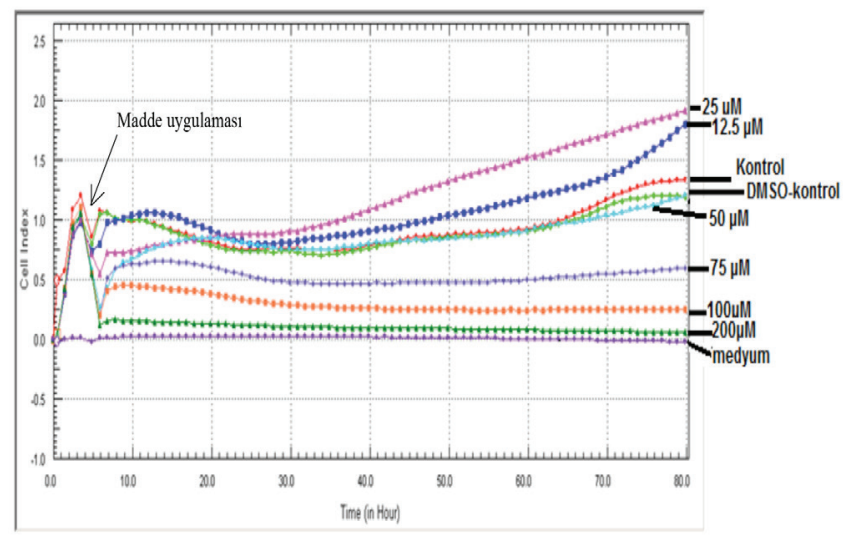

Şekil2.RTCA-DPsistemindeaprepitantkonsantrasyonlarının U87MG hücre proliferasyonuna etkileri. (RTCA-DP sisteminde proliferasyon eğrileri saatte bir alınan hücre indeks değerlerine göre monitörize edilmiştir).

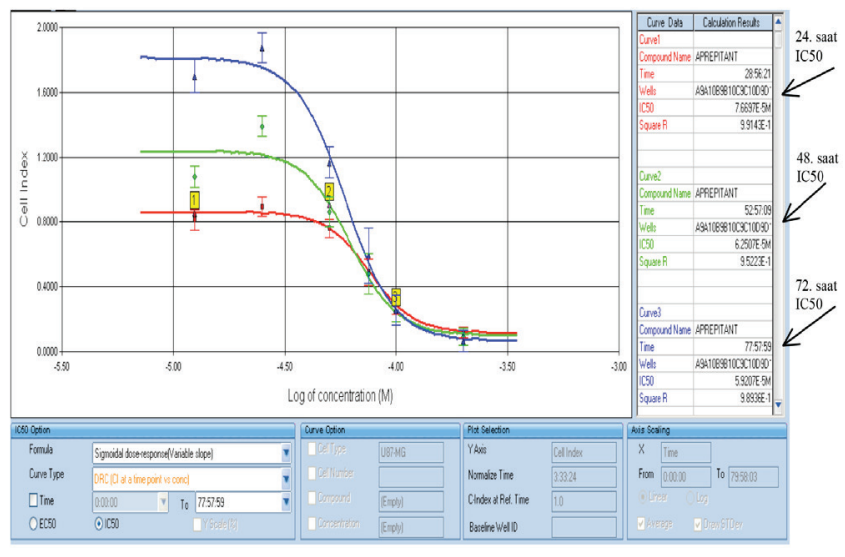

Şekil 3. RTCA-DP sisteminde aprepitant'in U87MG hücreleri üzerine 24,48 ve 72 . saatlerdeki hücre indeks değerlerine göre $\mathrm{IC}_{50}$ değerlerinin hesaplandığ 1 konsantrasyon-cevap eğrileri $\left(\mathrm{IC}_{50}\right.$ değerleri RTCA-DP sisteminde variable slope değerine göre analiz edilmiştir).

RTCA DP ile elde edilen hücre indeks değerlerine göre 12.5 ve $25 \mu \mathrm{M}$ düşük aprepitant konsantrasyonlarında, kontrole göre hücre proliferasyonlarında bir miktar artı̧̧ olduğu, ancak $50 \mu \mathrm{M}$ ve üzeri aprepitant konsantrasyonlarında ise zamana bağlı olarak hücre proliferasyonlarının azaldığ görülmektedir. Şekil 3'te U87MG hücreleri üzerinde 24, 48 ve 72 . Saatlerdeki aprepitant $\mathrm{IC}_{50}$ değerleri analizleri verilmiştir. Aprepitantın U87MG hücreleri üzerinde 24.

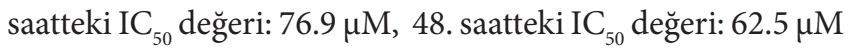
ve 72. saatteki $\mathrm{IC}_{50}$ değeri ise; $59.2 \mu \mathrm{M}$ olarak hücre indeks grafiğine göre cihazın analiz sistemi ile hesaplanmıştır. Bizim çalışmamızda aprepitantın glioma U87MG hücreleri üzerinde antiproliferatif etkilerinin gerçek zamanlı analiz sisteminde değerlendirildiği ilk çalışmadır.

Son yıllarda yapılan bir çalışmada GAMG glioma hücre dizisi üzerinde, aprepitantın sitotoksik etkisi tek başına \%7, antiviral ilaç olan ritonavir ve temozolamit ile kombine uygulanması sonrasinda sirasi ile \%34 ve \%19, temozolamit+ritonavir+aprepitant uygulamasından sonra da \%78 sitotoksik etki yaptığ belirlenmiştir. Özellikle bu sonucun ritonavir ve aprepitant arasındaki sinerjik etkiden olduğu rapor edilmiştir (30). Ayrıca beyin tümörü in vivo modelinde de, $3 \mathrm{mg} / \mathrm{kg} / g u ̈ n ~ d o z u n d a k i$ aprepitantın beyin tümörü çevresindeki ödemi iyileştirdiği açlklanmıştır (31). Meme kanser hücreleri ile yapılan başka bir çalışmada da aprepitantın farklı meme kanser hücreleri olan BT-474, MCF-7 and MDAMB-468 ve MT-3 üzerinde $\mathrm{IC}_{50}$ konsantrasyonunun 10-60 $\mu \mathrm{M}$ arasında değiştiği ve kanser hücreleri üzerinde önemli sitotoksik etki yaptığ açıklanmıştır (32). 


\section{Akım Sitometride Annexin V-PI Yöntemi ile Apoptotik Etkinin Değerlendirilmesi}

Flow sitometride apoptoz çalışmalarında da aprepitantın 24 . Saatte ki IC $_{50}$ konsantrasyonuna göre çalışılmış ve 24 . saatte ki $\mathrm{IC}_{50}$ değeri olan $76.9 \mu \mathrm{M}$ (yaklaşık hesaplanan $77 \mu \mathrm{M}$ ) kullanılmıştır. Bu değere göre de $\mathrm{IC}_{25} ; 38.5 \mu \mathrm{M}$ ve $\mathrm{IC}_{75} ; 115.5$ $\mu \mathrm{M}$ olarak hesaplanmıştır. U87-MG hücrelerinde aprepitantın $38.5\left(\mathrm{IC}_{25}\right), 77\left(\mathrm{IC}_{50}\right), 115.5\left(\mathrm{IC}_{75}\right) \mu \mathrm{M}$ konsantrasyonlarının 24. saatteki, akım sitometri analiz sonuçları Şekil 4 ve Tablo 1'de verilmiştir. Şekil 4 ve Tablo 1'de görüldüğü üzere, kontrole göre aprepitantın 24. saatteki erken ve geç apoptotik etkisi konsantrasyon artışına bağlı olarak artış göstermiştir. 38.5, 77 ve $115.5 \mu \mathrm{M}$ aprepitant konsantrasyonlarında erken apoptotik hücre değerleri, kontrole göre sırasılya; \%6.7, 11.9, 13.6 ve geç apoptotik değerleri ise \%7.2, 15.5 ve 36.3 olarak analiz edilmiştir.

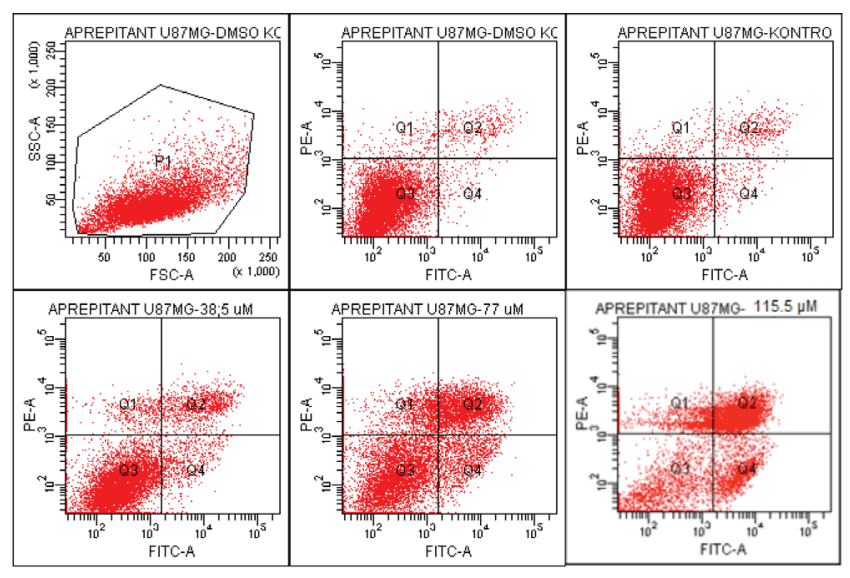

Şekil 4. Aprepitant konsantrasyonlarının (38.5, 77 ve 115.5 $\mu \mathrm{M})$ U87MG hücrelerinde, 24. saatteki apoptotik etkilerin Annexin V-PI yöntemi ile belirlenmesi.

Tablo 1. U87MG hücrelerinde aprepitantın Annexin V-PI analiz sonuçları.

\begin{tabular}{|c|c|c|c|c|}
\hline \multirow[b]{2}{*}{ GRUPLAR } & \multicolumn{4}{|c|}{ 24. Saat } \\
\hline & $\begin{array}{l}\text { Canlı } \\
\text { hücre } \\
\%(Q 3)\end{array}$ & $\begin{array}{r}\text { Nekrotik } \\
\text { hücre\% } \\
\text { (Q1) }\end{array}$ & $\begin{array}{c}\text { Erken } \\
\text { Apoptotik } \\
\text { hücre \% } \\
\text { (Q4) }\end{array}$ & $\begin{array}{c}\text { Geç } \\
\text { Apoptotik } \\
\text { hücre \% } \\
\text { (Q2) }\end{array}$ \\
\hline $\begin{array}{l}\text { Kontrol } \\
\text { (medyum) }\end{array}$ & 90.5 & 2.8 & 2.9 & 3.8 \\
\hline $\begin{array}{l}\text { Kontrol } \\
(\% 0.1 \\
\text { DMSO })\end{array}$ & 91.5 & 2.2 & 2.4 & 3.9 \\
\hline $\begin{array}{l}38.5 \mu \mathrm{M} \\
\text { Aprepitant }\end{array}$ & 82.3 & 3.8 & 6.7 & 7.2 \\
\hline $\begin{array}{l}77 \mu \mathrm{M} \\
\text { Aprepitant }\end{array}$ & 63.3 & 9.3 & 11.9 & 15.5 \\
\hline $\begin{array}{l}115.5 \mu \mathrm{M} \\
\text { Aprepitant }\end{array}$ & 41.3 & 8.8 & 13.6 & 36.3 \\
\hline
\end{tabular}

\section{Akım Sitometride Kaspaz-3 Aktivasyonu ile Apoptotik Etkinin Değerlendirilmesi}

U87-MG hücreleri üzerinde, aprepitantın $38.5,77$ ve 115.5 $\mu \mathrm{M}$ konsantrasyonlarının 24. saatteki, akım sitometride kaspaz-3 aktivasyonu analiz sonuçları Şekil 5 ve Tablo 2'de verilmiştir. Kaspaz-3 pozitif değeri, kontrole göre aprepitant konsantrasyonlarında (özellikle 38.5 ve $77 \mu \mathrm{M}$ da) artış göstermiştir.

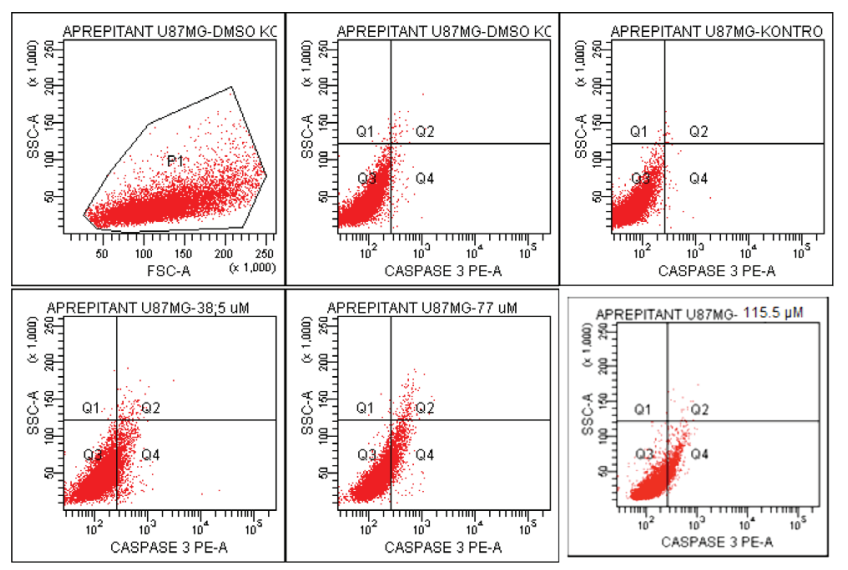

Şekil 5. Aprepitant konsantrasyonlarının (38.5, 77 ve 115.5 $\mu \mathrm{M})$ U87MG hücrelerinde 24. saatte kaspaz-3 aktivasyonuna etkileri.

Tablo 2. U87MG hücrelerinde aprepitant konsantrasyonlarının 24 saatlik inkübasyonunun kaspaz- 3 aktivasyonu analiz sonuçları

\begin{tabular}{lcc}
\hline \multicolumn{1}{c}{ GRUPLAR } & $\begin{array}{l}\text { Kaspaz-3 } \\
\text { negatif } \\
(\mathrm{Q} 3)\end{array}$ & $\begin{array}{l}\text { Kaspaz-3 pozitif } \\
\text { \% (Q4) }\end{array}$ \\
\hline Kontrol & 96.3 & $\mathbf{0 . 6}$ \\
Kontrol (\%0.1 DMSO) & 93.5 & $\mathbf{1 . 7}$ \\
$\mathbf{3 8 . 5} \boldsymbol{\mu M}$ Aprepitant & 86.4 & $\mathbf{8 . 3}$ \\
$\mathbf{7 7 \mu M}$ Aprepitant & 89.1 & 7.7 \\
$\mathbf{1 1 5 . 5} \mu \mathrm{M}$ Aprepitant & 93.6 & $\mathbf{4 . 4}$ \\
\hline
\end{tabular}

Çalışma sonucunda U87MG hücreleri üzerinde, aprepitantın apoptotik etkisinin olduğu ancak bu etkide kaspaz-3 aktivasyonundan başka, kaspaz-3 yolu dışında diğer hücresel apoptotik mekanizmaların (kaspaz-3 bağımsız mekanizma) etkili olabileceğini söyleyebiliriz. 
Akridin Turuncusu Floresan Boya ile Apoptotik Hücrelerin Mikroskobik İncelenmesi

NK-1 reseptör antagonisti olan aprepitantın apoptotik etkisini mikroskobik düzeyde araştırmak için akridin turuncusu ile boyama yöntemi kullanılmıştır. Aprepitant konsantrasyonları (38.5, 77 ve $115.5 \mu \mathrm{M})$ ile 24 saat inkübe edilen U87MG hücrelerinin 1 şı ve floresan mikroskobunda (Leica DM300 floresan mikroskobu) fotoğrafları çekilmiştir (Şekil 6).
A

Kontrol (\%0.1 DMSO)

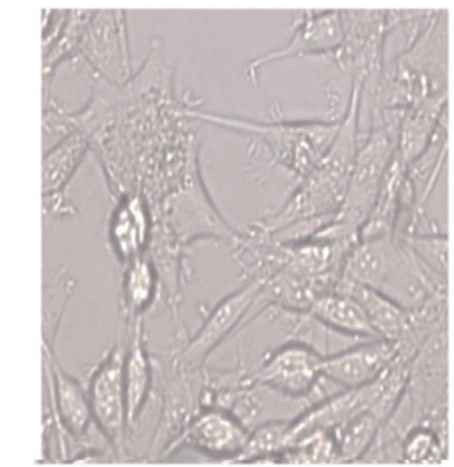

B

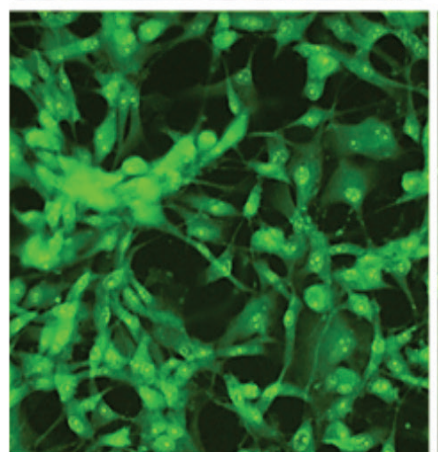

Aprepitant $\left(\mathrm{IC}_{25}: 38.5 \mu \mathrm{M}\right)$
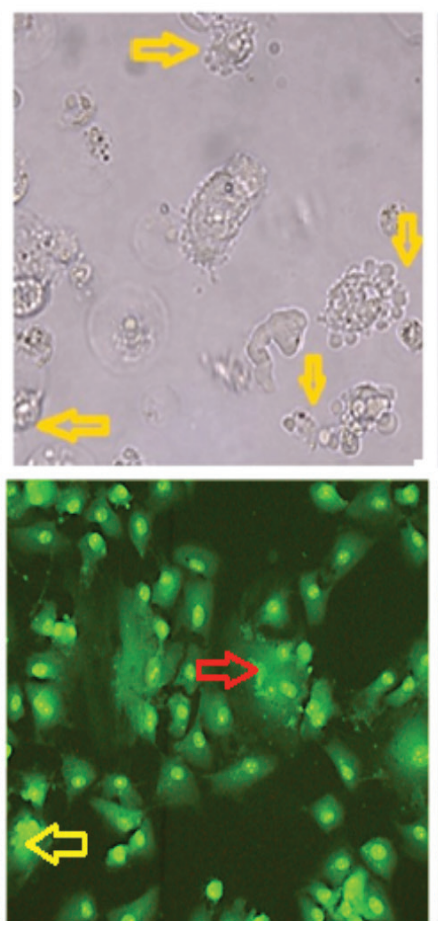

Aprepitant $\left(\mathrm{IC}_{50}: 77 \mu \mathrm{M}\right)$
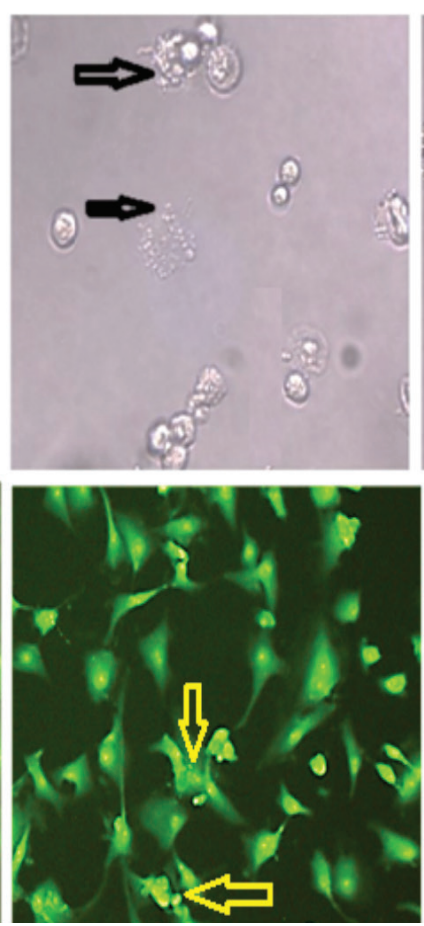

Aprepitant $\left(\mathrm{IC}_{75}: 114.5 \mu \mathrm{M}\right)$

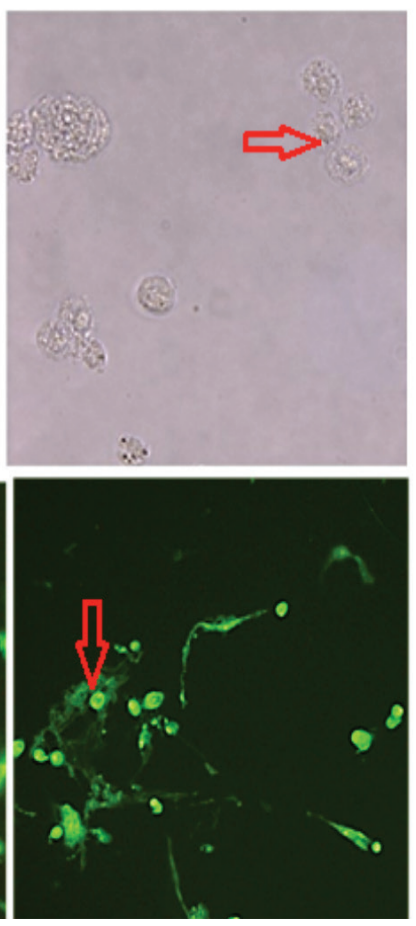

Şekil 6. Aprepitant konsantrasyonları ile 24 saat inkübe olan U87MG hücrelerinin morfolojik farklılıkları.

(A) Işı1k mikrıskobu görüntüleri (Mikroskop büyütmesi X400) ve, (B) Akridin turuncu boyanmış floresan mikroskop görüntüleri (Mikroskop büyütmesi: X200 ). Sarı ve siyah oklar apoptotik, kırmızı oklar nekrotik hücreleri göstermektedir.

Morfolojik görüntülerde, aprepitant konsantrasyonlarının uygulandığ 1 gruplarda apoptotik hücrelerin olduğu görülmektedir. Özellikle $\mathrm{IC}_{75}$ konsantrasyonda daha çok nekrotik hücrelerin artmış olduğu görülmekte olup, bu sonuç geç apoptotik hücre artışı ile paralellik göstermektedir.

NK-1 reseptörleri, hem plazma membranında hem de tümör hücrelerinin sitoplazmasinda, bazen de bu hücrelerin çekirdeklerinde yer alır. $(28,33)$. Bir nöropeptid olan substance $\mathrm{P}$ (SP), hem nöronal hem de immün hücreler tarafından üretilir. SP, vücutta yaygın bir şekilde dağılmış olan NK-1 reseptörüne yüksek afinite gösterir. SP, normal ve tümör hücrelerinde mitozu tetikler, hücreleri apoptozdan korur ve tümör hücrelerinin migrasyonunu indükler (34) Palma Mou ve arkadaşlarının yaptıkları bir çalışmada, insan hemokinin-1(taşikinin) tarafından NK1 reseptörünün aktive edildiği ve insan glioblastoma U251 ve U87 hücre migrasyonunu indüklediği açıklanmıştır. $\mathrm{Bu}$ migrasyon indüklenmesin de, hemokinin-1'in NK1 reseptörü aracıllğı ile AP-1 ve NF-kB aktivasyonuna neden olduğu ve bunu takiben de ERK, JNK ve Akt aktivasyonu ile MMP-2'nin upregülasyonuna neden olduğu bildirilmiştir (35). Bazı NK-1 reseptör antagonistlerinin farkı kanser hücrelerinde antikanser aktivitesi in vitro ve in vivo olarak gösterilmiştir. Klinik çalışmalarda da NK-1 reseptör antagonistlerinin farklı tümörlerde antitümor etkinliğinin değerlendirilmesi önem taşımaktadır. Özellikle emezis tedavisinde kullanılan ve minimal yan etkilere sahip bir ilaç olan aprepitant gibi NK-1 reseptör antagonistlerinin, antitümor etkisi klinik çalışmalarla araştırılmalıdır.

Son yıllarda kanser ölümlerin çoğunun malignant tümörlerde özellikle metastaz nedenli olması, taşikinin reseptörlerinin kanser kemoterapisinde önemli olabileceğini düşündürmüştür (28). Çalışmamızın sonucunda NK1 
reseptör antogonisti olan aprepitantın, metastatik karakter özelliğine sahip U87MG glioma hücrelerinde önemli sitotoksik, antiproliferatif ve apoptotik etkileri olduğunu belirledik. Sonuç olarak NK-1 reseptörlerinin bir terapötik

Antiproliferative and Apoptotic effects of Aprepitant on Human Glioblastoma U87MG Cells

\section{ABSTRACT}

Glioblastoma multiforme, is the most malignant glioma among other gliomas with high incidence. It has aggresive properties such as high proliferation, invasion and migration rates. Therefore, recently studies have focused on the development of new therapeutic targets in glioblastoma chemotherapy. Substance P, neurokinin-1 (SP/NK-1) receptor system has an important role in cancer development and metastasis. Therefore, NK-1 receptors are new therapeutic targets for glioblastoma therapy and development of NK-1 receptor antagonists.

In this study, antiproliferative and apoptotic effects of aprepitant which is an antiemetic drug commonly using in chemotherapy on human U87MG glioblastoma cells were investigated. Antiproliferative effects of aprepitant were evaluated by hedef olduğunu ve aprepitant gibi diğer NK-1 reseptör antagonistlerinin, kanser hücrelerine karşı geliştirilen antikanser ilaçlar arasında yeni umut vadedebileceği kanaatindeyiz.
MTT (3-(4,5-dimethylthiazol-2-yl)-2,5-diphenyltetrazolium bromide) and Real Time Analyses System (RTCA DP). Also apoptotic effects of aprepitant were evaluated by annexin- $\mathrm{V}$ PI and caspase- 3 activity by using flow cytometer. According to the cell index values obtained from real-time cell analysis system, with $50 \mu \mathrm{M}$ and higher concentrations, cell proliferation was decreased and IC50 values were determined as 76.9, 62.5 and $59.2 \mu \mathrm{M}$ for 24,48 and 72 hours respectively. Aprepitant showed significant antiproliferative effects on U87MG cells. Depending on increasing aprepitant concentrations, both early and late apoptotic cell ratios were increased. In addition, caspase- 3 activation was slightly increased with $\mathrm{IC}_{25}$ and $\mathrm{IC}_{50}$ concentrations of aprepitant according to the control group. As a result, aprepitant showed important antiproliferative and apoptotic effects on U87MG cells. In conclusion, NK-1 receptor antagonists may have a potential therapeutic role for human glioblastoma chemotherapy.

Keywords: aprepitant, U87MG cell, antiproliferative, apoptosis, neurokinin-1 receptor

\section{KAYNAKÇA}

1. Mut M. Glioblastomalarda Phosphatidylinositol 3-Kinase/Akt Yolu Üzerinden Elk-1 Aktivasyonunun Değerlendirilmesi. Doktora tezi, Hacettepe Üniversitesi, Sağllk Bilimleri Enstitüsü. 2007.

2. Kleihues P, Cavenee W. World Health Organization Classification of Tumours. Pathology and genetics of tumours of the nervous system. IARC, Lyon. 2000.

3. Hökfelt T, Pernow B, Wahren J. Substance P: A pioneer amongst neuropeptides. J Intern Med 2001; 249:27-40.

4. Muñoz M, Pérez A, Coveñas R, Rosso $M$, Castro E. Antitumoural action of L-733,060 on neuroblastoma and glioma cell lines. Arch Ital Biol 2004;142:105-12.

5. Muñoz M, Rosso M, González-Ortega A, Coveñas R. The NK-1 receptor antagonist L-732.138 induces apoptosis and counteracts substance P-related mitogenesis in human melanoma cell lines. Cancers 2010; 2: 611-23.

6. Muñoz M, Rosso M, Casinello F, Coveñas R. Paravertebral anesthesia:How substance $\mathrm{P}$ and the Nk-1 receptor could be involved in regional block and breast cancer recurrence. Breast Cancer Res Treat 2010; 122: 601-3.

7. Muñoz M, Coveñas R. Neurokinin-1 Receptor: A new promising target in the treatment of cancer. Discov Med 2010;10: 305-13.

8. Rupniak N, Kramer M. Substance P and Related Tachykinins. In: Neuropsychopharmacology-The Fifth Generation of Progress, Chapter 13. 2002, pp169-177.

9. Pennefather JN, Lecci A, Candenas ML, Patak E, Pinto FM,
Maggi CA. Tachykinins and tachykinin receptors: A growing family. Life Sci 2004;74:1445-63.

10. Mengi M. P Maddesinin Emosyonel Aktivite Üzerine Santral ve Periferik Etkileri, Bu etkilerde WIN-51708'in Rolü. Doktora tezi, İstanbul Üniversitesi, Sağlık Bilimleri Enstitüsü. 2009.

11. Muñoz M, Rosso M, Coveñas R. A new frontier in the treatment of cancer: NK-1 receptor antagonists. Curr Med Chem 2010;17: 504-16.

12. Diemunsch P, Grelot L. Potential of substance $P$ antagonists as antiemetics. Drugs 2000; 60:533-46.

13. Lang, K, Drell TL, Lindecke A, Niggemann B, Kaltschmidt C, Zaenker KS. Entschladen F. Induction of a metastatogenic tumor cell type by neurotransmitters and its pharmacological inhibition by established drugs. Int J Cancer 2004;112: 231-8.

14. Mosmann T. Rapid colorometric assay for cellular growth and survival: application to proliferation and cytotoxicity assay. J Immunol Method 1983; 65:55-63.

15. Freshney RI. Culture of Animal Cells, A Manual of Basic Technique. JohnWiley \& Sons, 5th Edition. 2005, pp359-372.

16. Dikmen M, Canturk Z, Ozturk Y, Tunalı Y. Investigation of the apoptotic effect of curcumin in human leukemia HL-60 cells by using flow cytometry. Cancer Biother Radiopharm 2010; 25:749-55

17. Limame R, Wouters A, Pauwels B, Fransen E, Peeters M, Lardon F, Wever OD, Pauwels P. Comparative analysis of dynamic cell viability, migration and invasion assessments by novel Real-Time Technology and classic endpoint assays. Plos One 2012; 7:1-12

18. Kaya Tilki E, Dikmen M, Öztürk Y. Effects of DNMT and 
HDAC Inhibitors (RG108 and Trichostatin A) on NGFinduced neurite outgrowth and cellular migration. Int J Pharmacol 2016; 12:351-60.

19. Gatti R, Belletti S, Orlandini G, Bussolati O, Dall'asta V, Gazzola GC. Comparison of Annexin V and calcein-AM as early vital markers of apoptosis in adherent cells by confocal laser microscopy. J Histochem Cytochem 1998;46:895-900.

20. Kopman G, Reutelingsperger CP, Kuijten GA, Keehnen RM, Pals ST, Van Oers NH. Annexin V for flow cytometric detection of phosphatidylserine expression on B cells undergoing apoptosis. Blood 1994;84:1415-20.

21. Overbeeke R, Steffens-Nakken H, Vermes I, Reutelingsperger C, Hanen C. Early features of apoptosis detected by four different flow cytometry assays. Apoptosis 1998;3:115.

22. Zhang G, Gurtu V, Kain SR, Yan G. Early detection of apoptosis using a fluorescent conjugate of Annexin V. Biotechniques 1997; 23:525-31.

23. Boğa C. Akım sitometri ile apoptozis tayini. İçinde:Klinik ve pratikte akım sitometri, 1. Baskı. Editör: Sözer O. Haberal Eğitim Vakfl, Ankara. 2009, pp 155-158.

24. Engür S, Dikmen M, Öztürk Y. Comparison of antiproliferative and apoptotic effects of a novel proteasome inhibitor MLN2238 with bortezomib on K562 chronic myeloid leukemia cells. Immunopharmacol Immunotoxicol 2016; 38: 87-97

25. Kaufmann SH, Hengartner MO. Programmed cell death: alive and well in the new millennium. Trends Cell Biol 2001; 11:526-34.

26. Slee EA, Adrain C, Martın SJ. Executioner caspases-3, -6, and -7 perform distinct, non-redundant roles during the demolition phase of apoptosis. J Biol Chem 2001;276:7320-6.

27. Chen WL, Pan L, Kinghorn AD, Swanson SM, Burdette JE. Silvestrol induces early autophagy and apoptosis in human melanoma cells. BMC Cancer 2016; 16:17
28. Muñoz M, Berger M, Rosso M, Gonzalez-Ortega A, Carranza A, Coveñas R. Antitumor activity of Neurokinin-1 receptor antagonists in MG-63 human osteosarcoma xenografts. Int J Oncol 2014;44: 137-46.

29. Muñoz M, Gonzalez-Ortega A, Robles-Frias M, Carranza A, Salinas-Martín M, Coveñas R. The Substance P/Neurokinin-1 receptor system in lung cancer: Focus on the antitumor action of Neurokinin-1 receptor antagonists. Peptides 2012:38:31825.

30. Kast RE, Ramiro S, Lladó S, Toro S, Coveñas R, Muñoz M. Antitumor action of temozolomide, ritonavir and aprepitant against human glioma cells J Neurooncol 2016;126:425-31.

31. Harford-Wright E, Lewis KM, Ghabriel MN, Vink R. Treatment with the NK1 antagonist emend reduces blood brain barrier dysfunction and edema formation in an experimental model of brain tumors. PLoS One 2014;9:e97002

32. Muñoz M, González-Ortega A, Salinas-Martín MV, Carranza A, Garcia-Recio S, Almendro V, Coveñas R.The neurokinin-1 receptor antagonist aprepitant is a promising candidate for the treatment of breast cancer. Int J Oncol 2014; 45: 1658-72.

33. Akazawa T, Kwatra SG, Goldsmith LE, Richardson MD, Cox EA, Sampson JH, Kwatra MM. A constitutively active form of Neurokinin 1 Receptor and Neurokinin 1 receptor-mediated apoptosis in glioblastomas. J Neurochem 2009; 109;1079-86.

34. Spitsin S, Stevens KE, Douglas SD. Expression of substance P, Neurokinin-1 receptor and immune markers in the brains of individuals with HIV-associated neuropathology. J Neurol Sci 2013; $334: 18-23$.

35. Mou L, Kang Y, Zhou Y, Zeng Q, Song H, Wang R. Neurokinin-1 receptor directly mediates glioma cell migration by up-regulation of matrix metalloproteinase-2 (MMP-2) and membrane type 1-matrix metalloproteinase (MT1-MMP). J Biol Chem 2013; 288: 306-18. 